\title{
PEMBERDAYAAN MASYARAKAT DESA PELANGKIAN MELALUI EDUKASI DAN LITERASI KEUANGAN PASAR MODAL MENUJU MASYARAKAT CERDAS BERINVESTASI
}

\author{
Meilaty Finthariasari' ${ }^{1}$, Erwin Febriansyah ${ }^{2}$, Katra Pramadeka $^{3}$ \\ ${ }^{1}$ Program Studi Manajemen \\ ${ }^{2}$ Program Studi Akuntansi \\ ${ }^{3}$ Program Studi Ekonomi Islam \\ Fakultas Ekonomi Universitas Muhammadiyah Bengkulu \\ Correponding author : mheyfinta@umb.ac.id
}

\begin{abstract}
ABSTRAK
Permasalahan yang terjadi di desa Pelangkian adalah kurangnya pemahaman masyarakat akan investasi bodong, sehingga masyarakat ini rentan menjadi sasaran pihak-pihak yang tidak bertanggung jawab yang ingin meraup keuntungan pribadi dengan cara menipu masyarakat yang tidak paham akan investasi. Hal ini terbukti dari penuturan Kades Desa Pelangkian, bahwa masyarakat Desa ini melaporkan sempat hampir menjadi korban penipuan investasi yang menawarkan keuntungan yang menggiurkan tanpa ada resiko.Dalam rangka mendukung program pemerintah memberantas investasi bodong dan meningkatkan jumlah investasi pasar modal di Indonesia, team pengabdian masyarakat akan mengadakan sosialisasi, edukasi, dan literasi tentang investasi legal yang ada di Indonesia. Adapun sasaran untuk diadakannya kegiatan saat ini adalah masyarakat Kabupaten Kepahiang Khususnya Desa Pelangkian. Tidak hanya sebatas sosialisasi dan pemahaman materi, team juga akan memberikan pengayaan berupa praktik investasi legal yang sangat terjangkau di pasar modal dan sangat menguntungkan untuk masyarakat karena akan dapat menambah penghasilan mereka.
\end{abstract}

Keyword : edukasi, literasi, investasi, pasar modal

\section{PENDAHULUAN}

Kurangnya pengetahuan masyarakat Provinsi Bengkulu terutama masyarakat di kabupaten mengenai investasi ilegal yang marak di Indonesia membuat masyarakat Bengkulu rentan terlibat dalam investasi bodong. Berdasarkan data dari Otoritas Jasa Keuangan (OJK) Provinsi Bengkulu dalam sepuluh tahun terakhir menyatakan bahwa kerugian masyarakat Provinsi Bengkulu atas investasi bodong dilaporkan mencapai $\mathrm{Rp} \quad 105,81$ Triliun (Bengkulu Ekspres, 2018). Berkaitan dengan hal ini, Otoritas Jasa Keuangan (OJK) Pusat dan Bareskrim Polri melalui Siaran Pers No.SP 05/VII/SWI/2019 sepakat untuk memberantas Fintech Peer-to-Peer Lending dan investasi illegal. 
Setidaknya saat ini di Indonesia terdapat 143 platform Fintech Peer-toPeer Landing (SWI, 2019) dan 14 perusahaan investasi ilegal (SWI, 2019) yangsedang marak dan sewaktuwaktu dapat dengan mudah masuk ke wilayah-wilayah desa, dimana diketahui masyarakatnya mudah untuk diajak bergabung karena tingkat pengetahuan yang minim. Desa Pelangkian adalah salah satu desa yang pernah hampir menjadi korban penipuan dari yang berkedok investasi yang menawarkan keuntungan yang menggiurkan tanpa ada resiko.

Kegiatan edukasi dan literasi yang memang belum pernah diterima oleh masyarakat di Desa Pelangkian yang ada di Kabupaten Kepahiang Provinsi Bengkulu perlu menjadi perhatian bagi para tenaga pendidik (dosen) untuk juga fokus dalam memberikan pemahaman sejak dini mengenai bahaya investasi bodong dan pemahaman tentang pasar modal Indonesia. Dalam kegiatan edukasi dan literasi yang akan dilakukan ini memerlukan berbagai sarana pendukung seperti modul yang berkaitan dengan pasar modal misalnya sejarah pasar modal, pengetahuan pasar modal, Yuk Belajar Saham untuk pemula, dan sebagainya. Disamping sarana yang berupa modul dan alat peraga ini, dibutuhkan pula prasarana yaitu pemateri yang kompeten dibidangnya dari OJK, Bursa Efek Indonesia Cabang Bengkulu, dan pelaku pasar modal.

Selama 2-3 tahun terakhir berbagai kegiatan edukasi dan literasi keuangan dan pasar modal telah dilakukan di Kota Bengkulu baik kepada siswa/i SMA, mahasiswa, ASN, wiraswasta, guru, dsb. Namun untuk kegiatan yang sama di Kabupaten Provinsi Bengkulu masih dirasa kurang karena akses, sarana, dan prasarana yang belum memadai bahkan dirasa sangat kurang.

\section{KAJIAN PUSTAKA}

\subsection{Edukasi}

Pengertian edukasi adalah proses kegiatan belajar setiap individu atau kelompok yang tujuannya untuk meningkatkan kualitas dari pola pikir, pengetahuan serta mengembangkan potensi dari masing-masing individu. Proses edukasi ini dalam kehidupan sehari - hari lebih dikenal dengan sebutan proses belajar. Edukasi merupakan proses belajar dari tidak tahu menjadi tahu.

Edukasi bisa didapatkan pada pembelajaran formal, non formal, dan informal. Pengertian edukasi menurut KBBI yaitu proses pengubahan sikap dan perilaku seseorang atau kelompok dalam usaha mendewasakan diri melalui upaya pengajaran, pelatihan, proses, dan cara mendidik.

\section{Edukasi memiliki beberapa} tujuan, berikut diantaranya:

- Meningkatkan kecerdasan.

- Merubah kepribadian manusia suapaya memiliki akhlak yang terpuji.

- Menjadikan mampu untuk mengontrol diri.

- Meningkatkan keterampilan.

- Bertambahnya kreativitas pada hal yang dipelajari.

- Mendidik manusia menjadi lebih baik dalam bidang yang ditekuni.

Seperti yang sudah sedikit dijelaskan di atas bahwa edukasi 
memiliki tiga macam atau jenis yaitu edukasi formal, non formal, dan edukasi informal. Berikut penjelasan dari macam-macam edukasi:

1. Formal

Proses pembelajaran ini umum diselenggarakan di sekolah dan ada peraturan yang berlaku serta harus ditaati ketika sedang mengikuti proses pembelajaran tersebut, lalu ada pihak terkait yang mengawasi proses pembelajaran di sekolah. Di Indonesia, pendidikan formal yang bisa ditempuh oleh setiap individu adalah mulai dari jenjang SD, SMP, dan SMA, hingga pendidikan tinggi.

\section{Non Formal}

Edukasi non formal biasanya banyak ditemukan di lingkungan tempat tinggal, contohnya terdapat tempat pendidikan baca tulis Al Quran di masjid, lalu kursus-kursus yang banyak terdapat di lingkungan seperti kursus mobil, kursus musik, dan kursus-kursus lain.

\section{Informal}

Sedangkan edukasi informal merupakan jalur pendidikan yang terdapat di keluarga dan lingkungan sekitar rumah. Di dalam edukasi informal terdapat proses pembelajaran secara mandiri dan dilakukan atas dasar kesadaran serta rasa tanggungjawab yang dimiliki.

Manfaat Edukasi, diantaranta:

- Mencerdaskan kehidupan bangsa untuk membangun peradaban negara

- Memberikan pengetahuan luas tentang apa yang dipelajari.

- Mengembangkan kepribadian manusia menjadi lebih bermartabat.

- Mengembangkat bakat yang telah dimiliki sehingga lebih berpotensi.
- Memperbaiki kesalahan seseorang agar menjadi lebih baik.

- Membekali manusia untuk menyongsong masa depan yang cerah

\subsection{Inklusi Keuangan}

Inklusi keuangan pada dasarnya mengacu pada jumlah orang yang menjadi nasabah atau pengguna jasa keuangan.Beberapa contoh jasa keungan yang dimaksud meliputi semua jenis layanan perbankan dan juga asuransi.

Inklusi keuangan memiliki banyak manfaat. Menurut Bank Dunia, peningkatan inklusi keuangan dengan nilai satu persen saja, maka pertumbuhan ekonomi bertambah 0,03 persen. Selain itu, inklusi keuangan juga diharapkan mampu memberi sumbangsih lebih untuk negara, diantaranya sebagai berikut:

- Mendukung stabilitas sistem keuangan

- Meningkatkan efisiensi ekonomi

- Mengurangi shadow banking atau irresponsible finance

- Mendukung ekspansi pasar keuangan

- Menyumbangkan potensi pasar baru bagi perbankan

- Meningkatkan Human Development Index (HDI) Indonesia

- Berkontribusi positif terhadap pertumbuhan ekonomi lokal dan nasional secara kontinu

\subsection{Inklusi dan Literasi Keuangan}

\begin{tabular}{llll}
\multicolumn{2}{r}{ Berbicara mengenai } & perbedaan \\
inklusi dan literasi & keuangan, \\
keduanya tentu memiliki & keterkaitan
\end{tabular} 
satu sama lain. Inklusi tanpa literasi mumpuni tidak akan bermakna signifikan, terutama terhadap perekonomian. Jika inklusi berhubungan dengan jumlah pengguna jasa keuangan, literasi keuangan lebih fokus kepada pengelolaan uang yang dimiliki. Seseorang dengan literasi keuangan yang baik, umumnya tahu bagaimana cara memanfaatkan uang semaksimal mungkin. Sehingga dengan demikian adanya inklusi tadi tidak sia-sia.

Ada empat tingkat literasi keuangan penduduk Indonesia berdasarkan survei OJK pada tahun 2013, yakni:

- Well literate $(21,84 \%)$ : memiliki pengetahuan dan keyakinan akan berbagai lembaga jasa keuangan serta produk jasa keuangan, termasuk fitur, manfaat dan risiko, hak dan kewajiban terkait produk dan jasa keuangan, serta memiliki keterampilan dalam menggunakan produk dan jasa keuangan.

- Sufficient literate (75,69 \%): memiliki pengetahuan dan keyakinan tentang lembaga jasa keuangan serta produk dan jasa keuangan, termasuk fitur, manfaat dan risiko, hak dan kewajiban terkait produk dan jasa keuangan.

- Less literate (2,06 \%): cenderung memiliki pengetahuan tentang lembaga jasa keuangan, produk dan jasa keuangan.

- Not literate $(0,41 \%)$ : tidak memiliki pengetahuan dan keyakinan terhadap lembaga jasa keuangan serta produk dan jasa keuangan, serta tidak memiliki keterampilan dalam menggunakan produk dan jasa keuangan.

Untuk mengurangi ketimpangan ekonomi, maka terhitung sejak bulan Oktober 2016 lalu, Otoritas Jasa Keuangan telah menginisiasi sebuah bulan inklusi keuangan. Inklusi keuangan merupakan salah satu senjata yang dipercaya dapat menurunkan tingkat kemiskinan serta mengurangi kesenjangan ekonomi di masyarakat. Bank Indonesia menjelaskan bahwa tidak ada definisi yang baku dari ekonomi inklusif sendiri. Ekonomi inklusif dapat diartikan sebagai suatu keadaan dimana semua orang dari seluruh lapisan masyarakat dapat menikmati layanan dan akses keuangan secara efektif dan efisien.Ada pula yang mengaitkan istilah ekonomi inklusif dengan banyaknya nasabah dalam suatu bank.Hal ini juga tidak salah, mengingat bank merupakan salah satu media pelayanan dan akses keuangan yang dapat memberikan layanan keuangan secara praktis.

Manfaat Inklusi Keuangan secara tidak langsung, yaitu:

- Mengurangi tingkat pengangguran

- Menurunkan tingkat kemiskinan

- Meminimalisir

terjadinya kesenjangan sosial

Peningkatan inklusi keuangan juga diharapkan mampu memberi dampak positif bagi negara, antara lain:

- Mendukung stabilitas sistem keuangan yang kemudian berpengaruh pada pertumbuhan ekonomi Indonesia

- Meningkatkan efisiensi ekonomi dan mengurangi distorsi 
ekonomi dalam proses produksi barang dan jasa di masyarakat

- Mengurangi shadow banking atau irresponsible finance pada kegiatan finansial di masyarakat

- Mendukung ekspansi pasar keuangan dalam proses dan kegiatan keuangan

- Menyumbang potensi pasar baru bagi industri perbankan

- Meningkatkan Human Development Index (HDI) Indonesia yang berpengaruh pada kemajuan negara

- Berkontribusi positif terhadap pertumbuhan ekonomi lokal dan nasional secara berkelanjutan dan stabil

- Mengurangi kesenjangan dan rigiditas pendapatan yang rendah sehingga dapat berpengaruh pada kesejahteraan masyarakat

\subsection{Investasi}

Secara umum, pengertian dari investasi adalah penanaman aset atau dana yang dilakukan oleh sebuah perusahaan atau perorangan untuk jangka waktu tertentu demi memperoleh imbal balik yang lebih besar di masa depan. Jenis-jenis investasi yang bisa memberikan imbal hasil ada berbagai macam. Ada investasi emas, properti, deposito bank, reksadana, saham, hingga investasi pada mata uang asing (forex). Setiap jenis investasi ini memiliki karakteristik masing-masing yang patut untuk dicermati.

Pada masyarakat yang lebih konvensional, jenis investasi paling populer adalah membeli emas atau properti.Logam mulia yang banyak dikoleksi sebagai perhiasan memang mudah untuk diperjualbelikan sewaktu-waktu, tapi risiko hilang membuat orang semakin lama semakin enggan untuk menyimpan emas.Membeli properti seperti rumah atau tanah, juga banyak dilakukan sebagai salah satu langkah berinvestasi.

Pertimbangan-pertimbangan yang perlu dilakukan agar tidak salah langkah dalam berinvestasi antara lain adalah:

- Harus ada unsur ketersediaan dana (aset). Dalam berinvestasi, kita harus menyesuaikan kemampuan finansial kita sendiri.Jangan memaksakan diri untuk menanamkan modal kepada suatu bisnis yang jumlahnya di luar kemampuan kita.Seperti yang telah dijelaskan di atas,

- Selalu pertimbangkan resiko dari investasi. Perlu diingat bahwa tidak ada investasi yang tidak memiliki resiko.

\subsection{Pasar Modal}

Pasar modal (capital market) merupakan pasar untuk berbagai instrumen keuangan jangka panjang yang bisa diperjualbelikan, baik surat utang (obligasi), ekuiti (saham), reksa dana, instrumen derivatif maupun instrumen lainnya. Pasar modal merupakan sarana pendanaan bagi perusahaan maupun institusi lain (misalnya pemerintah), dan sebagai sarana bagi kegiatan berinvestasi. Dengan demikian, pasar modal memfasilitasi berbagai sarana dan prasarana kegiatan jual beli dan kegiatan terkait lainnya. 
$\begin{array}{rrr}\text { Instrumen } & \text { keuangan } & \text { yang } \\ \text { diperdagangkan di pasar moda }\end{array}$ merupakan instrumen jangka panjang (jangka waktu lebih dari 1 tahun) seperti saham, obligasi, waran, right, reksa dana, dan berbagai instrumen derivatif seperti option, futures, dan lain-lain. Undang-Undang Pasar Modal No. 8 tahun 1995 tentang Pasar Modal mendefinisikan pasar modal sebagai "kegiatan yang bersangkutan dengan Penawaran Umum dan perdagangan Efek, Perusahaan Publik yang berkaitan dengan Efek yang diterbitkannya, serta lembaga dan profesi yang berkaitan dengan Efek".

Pasar Modal memiliki peran penting bagi perekonomian suatu negara karena pasar modal menjalankan dua fungsi, yaitu pertama sebagai sarana bagi pendanaan usaha atau sebagai sarana bagi perusahaan untuk mendapatkan dana dari masyarakat pemodal (investor). Dana yang diperoleh dari pasar modal dapat digunakan untuk pengembangan usaha, ekspansi, penambahan modal kerja dan lain-lain. Kedua, pasar modal menjadi sarana bagi masyarakat untuk berinvestasi pada instrument keuangan seperti saham, obligasi, reksa dana, dan lain-lain. Dengan demikian, masyarakat dapat menempatkan dana yang dimilikinya sesuai dengan karakteristik keuntungan dan risiko masing-masing instrument.

\section{METODE PELAKSANAAN KEGIATAN}

Pelaksanaan

kegiatan

pengabdian dilakukan pada Desa

Pelangkian Kabupaten Kepahiyang dari tanggal 8 Agustus s.d 15 Agustus 2019. Adapun metode pelaksanaan kegiatan ini adalah sebagai berikut:
1. Pengenalan dan Pemberian Materi tentang Investasi Legal dan Pasar Modal yang ada di Indonesia.

2. Diskusi Seputar Investasi Bodong dan Pasar Modal. Untuk memperdalam materi yang telah disampaikan, maka perlu adanya diskusi oleh pihak pemberi materi dengan menggunakan metode interaktif QnA (question\& answer).

3. Simulasi Stocklab

4. Membentuk Kelompok Studi Pasar Modal (KSPM)

5. Sekolah Pasar Modal (SPM). Sekolah pasar modal ini merupakan kegiatan praktek secara nyata mengenai bentuk pasar modal dengan menggunakan aplikasi pasar modal yang telah tersedia pada Bursa. Disini peserta akan dibimbing dan dibina langsung secara mendalam tentang bagaimana cara menggunakan aplikasi transaksi pasar modal. Para peserta dapat memahami bagaimana mengelola investasi pada rekening (portofolio) mereka masing-masing. Peserta juga akan diajarkan teknikal analisis dan fundamental analisis dalam memilih investasi saham yang tepat. Sehingga dengan demikian peserta tidak akan salah memilih investasi yang hanya akan dapat merugikan mereka saja.

\section{HASIL DAN PEMBAHASAN}

Kegiatan edukasi dan literasi yang dilakukan di Desa Pelangkian ini, dilakukan dengan bantuan dari pihak Bursa Efek Indonesia Kantor Perwakilan Bengkulu. Dalam kegiatan pemberian materi ini diadakan dua sesi, yaitu: 
- Sesi pertama: materi tentang investasi legal dan Ilegal akan disampaikan oleh pemateri dari pihak OJK,

- Sesi kedua: materi pengenalan pasar modal akan disampaikan oleh pemateri dari pihak Bursa Efek Indonesia Kantor Perwakilan Bengkulu, dosen, dan praktisi pasar modal.

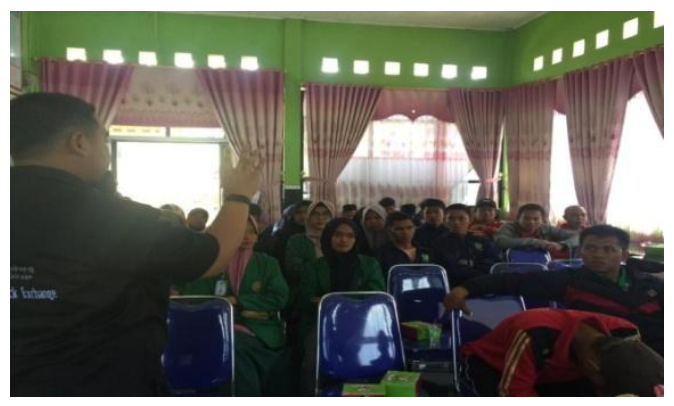

Sumber: Dokumentasi, 2019

Adapun materi yang diberikan tentang waspada investasi bodong yaitu,

1. Ciri-ciri investasi bodong,

2. Pengertian pasar modal

3.

entuk nyata pasar modal melalui simulasi permainan yang mudah dipahami bagi masyarakat. Simulasi ini dinamakan stocklab game. Dimana dalam kegiatan ini peserta dapat mempraktekan atau mengaplikasikan bagaimana masuk dan terjun langsung ke dunia pasar modal melalui media education game. Dalam kegiatan ini peserta akan dibagi dalan beberapa kelompok untuk dapat mengaplikasikan simulasi ini akan didampingi oleh para pakar stocklab dari Bursa Efek Indonesia Cabang Bengkulu dan mahasiswa KSPM Universitas Muhammadiyah Bengkulu.

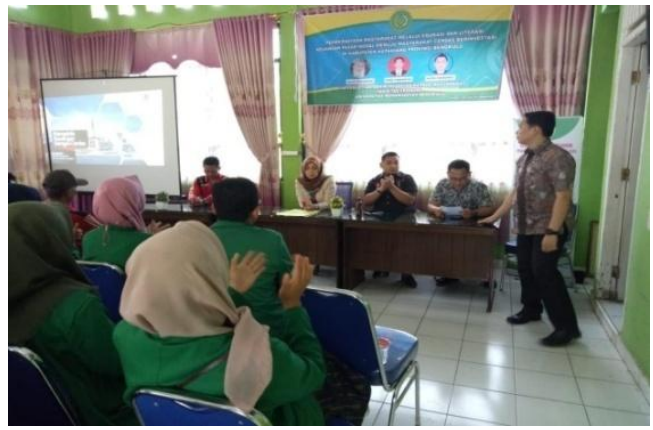

Sumber: Dokumentasi, 2019

Dengan mengetahui cirri-ciri investasi bodong, masyawakat dapat terhindar dari bahaya kerugian material yang disebabkan dari salah memilih investasi yang tidak legal/investasi bodong. Kemudian pelaksanaan kegiatan ini juga melakukan pembentukan Kelompok Studi Pasar Modal (KSPM) Desa Pelangkian yang bertujuan untuk dapat mempermudah masyarakat mendapatkan akses ke Bursa Efek Cabang Bengkulu ketika nanti kegiatan pembelajar dan penyuluhan ini selesai dilakukan dengan dipandu dan dibimbing oleh dosen dan mahasiswa KSPM Universitas Muhammadiyah Bengkulu.

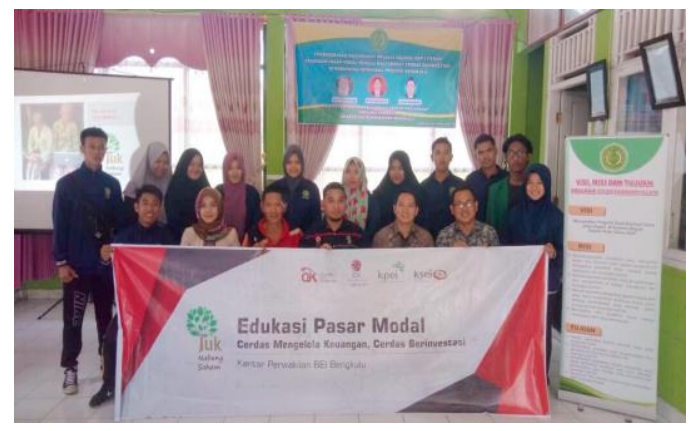

Sumber: Dokumentasi, 2019 


\section{DAFTAR PUSTAKA}

https://kiajar.com/pengertian-edukasi/

https://koinworks.com/blog/manfaatinklusi-keuangan/

https://koinworks.com/blog/jenisinvestasi-yang-cocok-untukpemula/

https://www.akseleran.co.id/blog/peng ertian-investasi-dan-caraberinvestasi/

https://www.cekaja.com/info/mengena l-inklusi-keuangan-pengertianmanfaat-dan-inovasinya-untuknegaral

https://www.idx.co.id/investor/pengant ar-pasar-modal/

https://www.ojk.go.id/id/kanal/pasarmodal/tentang-pasarmodal/Pages/Tugas.aspx

https://www.seputarforex.com/artikel/ definisi-dan-pengertianinvestasi-119302-31

https://www.seputarforex.com/artikel/ pengetahuan-dasar-pasarmodal-yang-harus-andaketahui-122372-34

https://www.simulasikredit.com/apaitu-inklusi-keuangan/

Universitas Muhammadiyah Bengkulu, 2018. Pedoman Proposal Pengabdian Masyarakat. LPPM 